\title{
Correction to: Social capital and willingness to migrate in post-communist countries
}

\author{
Peter Huber ${ }^{1} \cdot$ Stepan Mikula ${ }^{2}$
}

Published online: 23 November 2018

(c) Springer Science+Business Media, LLC, part of Springer Nature 2018

\section{Correction to: Empirica \\ https://doi.org/10.1007/s10663-018-9417-7}

In the original publication of the article, the below mentioned acknowledgement section is missing.

Acknowledgements Financial support from the Czech Science Foundation, Grant No. 15-17810S, and the hospitality of Spolek in Brno is gratefully acknowledged. We thank two anonymous reviewers, Josef Montag and participants at the 2017 Geoffrey J. D. Hewings Regional Economics Workshop for helpful comments. Any remaining mistakes are our own.

The original article can be found online at https://doi.org/10.1007/s10663-018-9417-7.

Peter Huber

Peter.Huber@wifo.ac.at

Stepan Mikula

stepan.mikula@econ.muni.cz

1 Austrian Institute of Economic Research, Vienna, Austria

2 Masaryk University, Lipová 41a, 60200 Brno, Czech Republic 